\title{
DEGRADATION MECHANISM STUDY OF SELECTED THERMALLY SPRAYED COATINGS IN THE ENVIRONMENT OF STEAM TURBINE
}

\author{
1'Sárka HOUDKOVÁ, ${ }^{1}$ Michaela PRANTNEROVÁ, ${ }^{2}$ Martin BYSTRIANSKÝ, ${ }^{3}$ František LUKÁČ \\ ${ }^{1}$ Research and Testing Institute Pilsen, Pilsen, Czech Republic, EU, \\ houdkova@vzuplzen.cz,prantnerova@vzuplzen.cz \\ ${ }^{2}$ RTI-University of West Bohemia, Pilsen, Czech Republic, EU, mbyst@rti.zcu.cz \\ 3Institute of Plasma Physics ASCR, Prague, Czech Republic, EU, lukac@ipp.cas.cz
}

https://doi.org/10.37904/metal.2019.725

\begin{abstract}
In the paper, the influence of high temperature and hot pressure steam on the microstructure and phase composition of HVOF sprayed wear resistant $\mathrm{Cr}_{3} \mathrm{C}_{2}-\mathrm{NiCr}$ coating and flame sprayed NiCrAl-Bentonite abradable coating is studied. Both the results of laboratory oxidation tests and the long-term exposition tests in the steam turbine are presented. The mechanism of selective carbide oxidation was observed in both laboratory test and long-term oxidation test in the case of $\mathrm{HVOF} \mathrm{Cr}_{3} \mathrm{C}_{2}-\mathrm{NiCr}$ coating. The oxidation of NiCrAl matrix of flame spray abradable coating is described. Both coatings suffered from oxidation, but their integrality was not disrupted even after 5.5 years of exposition in steam turbine environment.
\end{abstract}

Keywords: Steam turbine, degradation, thermal spray, abradable, $\mathrm{Cr}_{3} \mathrm{C}_{2}-\mathrm{NiCr}$, NiCrAl-Bentonite

\section{INTRODUCTION}

The requirements imposed on the materials of in steam turbine components differ according to components purpose and location. Nevertheless, all used materials have to resist degradation of their properties due to the influence of environment. The increased temperature, reaching up to $600^{\circ} \mathrm{C}$, can cause the devastating loss of mechanical properties or oxidation level leading to fatal failure (Figure 1). That is why the attention has been paid to the study of bulk materials degradation already several decades. The same attention has to be paid to the evaluation of degradation mechanisms which take place in coatings, applied on the surface of steam turbine components to increase their functional properties, such as wear or oxidation resistance or for other purposes, such as thermal barrier coatings or abradable coatings.

HVOF sprayed $\mathrm{Cr}_{3} \mathrm{C}_{2}-\mathrm{NiCr}$ coatings are widely applied on the surface of components, working in high temperature environment up to $870{ }^{\circ} \mathrm{C}$. Its main purpose is to increase the components wear and oxidation resistance. The microstructure and properties of HVOF sprayed $\mathrm{Cr}_{3} \mathrm{C}_{2}-\mathrm{NiCr}$ was studied many times, as well as the influence of the high temperature [1,2]. Based on these studies, the stability of the HVOF sprayed $\mathrm{Cr}_{3} \mathrm{C}_{2-}$ $\mathrm{NiCr}$ coating at high temperature was proved. On the other hand, only minor attention was paid to the evaluation of the influence of steam turbine environment, where the combination of corrosive-aggressive steam and increased pressure appears. In the study of Matthews [3], the mechanism of selective oxidation of carbides was suggested, possible responsible for above mentioned coating degradation.

The abradable coatings, such as flame sprayed NiCrAl-21\%bentonite coating, are used to increase the efficiency of aircraft or industrial gas turbines through decrease the necessary clearance between the rotating blade tips and the casing. The main abradable coating requirements are the easy abradability, oxidation and erosion resistance, and low thermal conductivity together with thermal shock resistance. To fulfill the expectation, the porous microstructure, consisting of metal-alloy matrix (usually $\mathrm{Ni}$ or $\mathrm{Al}$ based) and solid lubricant, such as graphite or bentonite [4-6]. Besides the above-mentioned characteristics, the stability of microstructure and mechanical properties in high temperature environment as also the crucial [7]. 

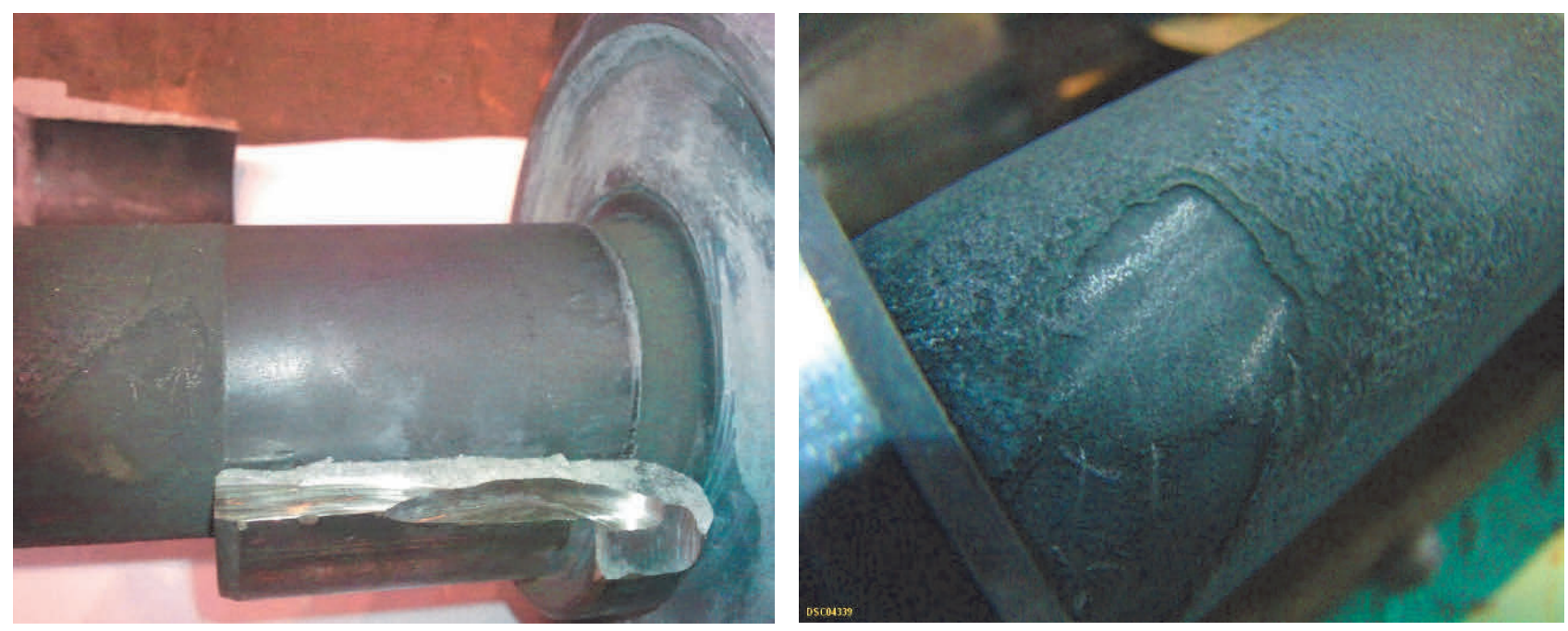

Figure 1 Failure of $\mathrm{Cr}_{3} \mathrm{C}_{2}-25 \%$ NiCr HVOF sprayed coating of a steam distribution component TG 23 ETU (2012) [8]

In the literature, the results of laboratory tests are usually presented, performed in conditions, that are supposed to simulate the real working conditions or that are even severe. The drawback of these experiments is their shortness, compare to expected lifetime of coated parts. In this work, the results of long-term exposition in real steam turbine working condition are presented, and compare to the short-term laboratory tests.

\section{EXPERIMENTAL}

\subsection{Coatings deposition}

The commercially available Amperit 588.074 powder was used to deposit the hard, wear resistant $\mathrm{Cr}_{3} \mathrm{C}_{2-}$ $25 \% \mathrm{NiCr}$ coating, using the HP/HVOF TAFA JP5000 spraying device. The previously optimized process parameters were used [9] to produce the coating with high hardness and low porosity. The commercially available abradable material Durabrade 2313 from Oerlicon Metco was used to deposit a NiCrAl-21\% Bentonite coating using the $6 \mathrm{P}-\mathrm{Il}$ flame spraying gun. Both coatings were sprayed onto grit blasted $\left(\mathrm{Al}_{2} \mathrm{O}_{3}\right.$; F22) surface of $\mathrm{X} 22$ steel bar, $25 \mathrm{~mm}$ diameter. The surface of $\mathrm{Cr}_{3} \mathrm{C}_{2}$-NiCr coating were consequently grinded, while the abradable Durabrade 2313 coating was left in the as-spread state, similarly to the application condition.

\subsection{Characterization}

The sample bars were placed into the exposure channel ETU21 of power plant Tušimice, together with $s$ of other samples of tested steels and surface treatments [10]. The temperature in exposure channel reached $540{ }^{\circ} \mathrm{C}$ and the pressure of the steam $17 \mathrm{MPa}$. After certain time periods, the samples were checked and analyzed. The samples, reported in this study, was exposed for 5.5 years (Figure 2).

The microstructure of the coatings was analyzed on the coating's cross sections (grinded and polished by an automatic Leco grinding and polishing equipment) by optical microscope Nikon Epiphot 200 and Scanning electron microscope EVO MA25, Zeiss, (with LaB6 thermal filament), equipped by EDX detector SDD X-Max 20, Oxford Instruments.

The coatings' phase composition was evaluated by means of powder X-ray diffraction (PXRD), using the D8 Discover powder diffractometer in Bragg-Brentano geometry with 1D detector and CuKa radiation. 
The microhardness of the $\mathrm{Cr}_{3} \mathrm{C}_{2}-\mathrm{NiCr}$ coating was measured on the ground cross-sections of as-sprayed and exposed coatings using the HV0.3 method. For each coating, at least 10 indents were done, and the average value is reported.

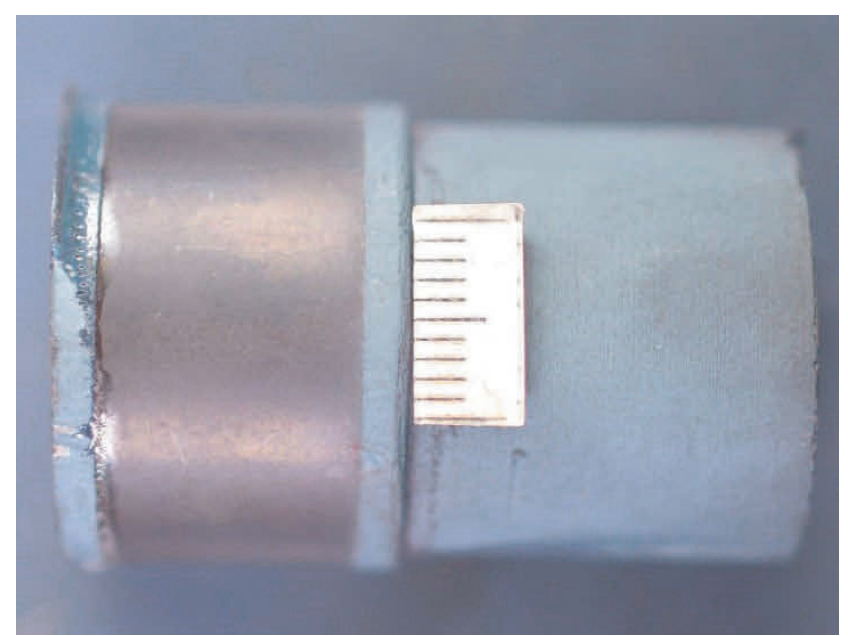

a)

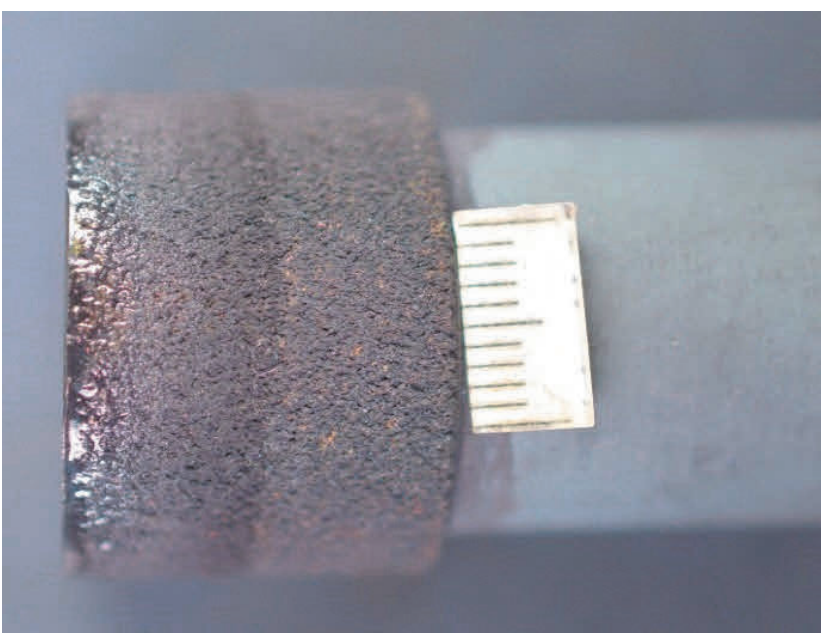

b)

Figure 2 Samples after 6 years of exposition: a) HVOF $\mathrm{Cr}_{3} \mathrm{C}_{2}-25 \% \mathrm{NiCr}$;

b) flame sprayed NiCrAl-Bentonite

\section{RESULTS AND DISCUSSION}

\section{1. $\mathrm{Cr}_{3} \mathrm{C}_{2}-25 \% \mathrm{NiCr}$ coating}

After 5.5 years of exposition, the HVOF sprayed $\mathrm{Cr}_{3} \mathrm{C}_{2}-\mathrm{NiCr}$ coating surface was covered by a thin, well adhered layer Cr-based oxides. No massive oxidation or delamination was observed on the surface (Figure $\mathbf{2 a}$ ) or cross section (Figure 3 ) of the analyzed sample.
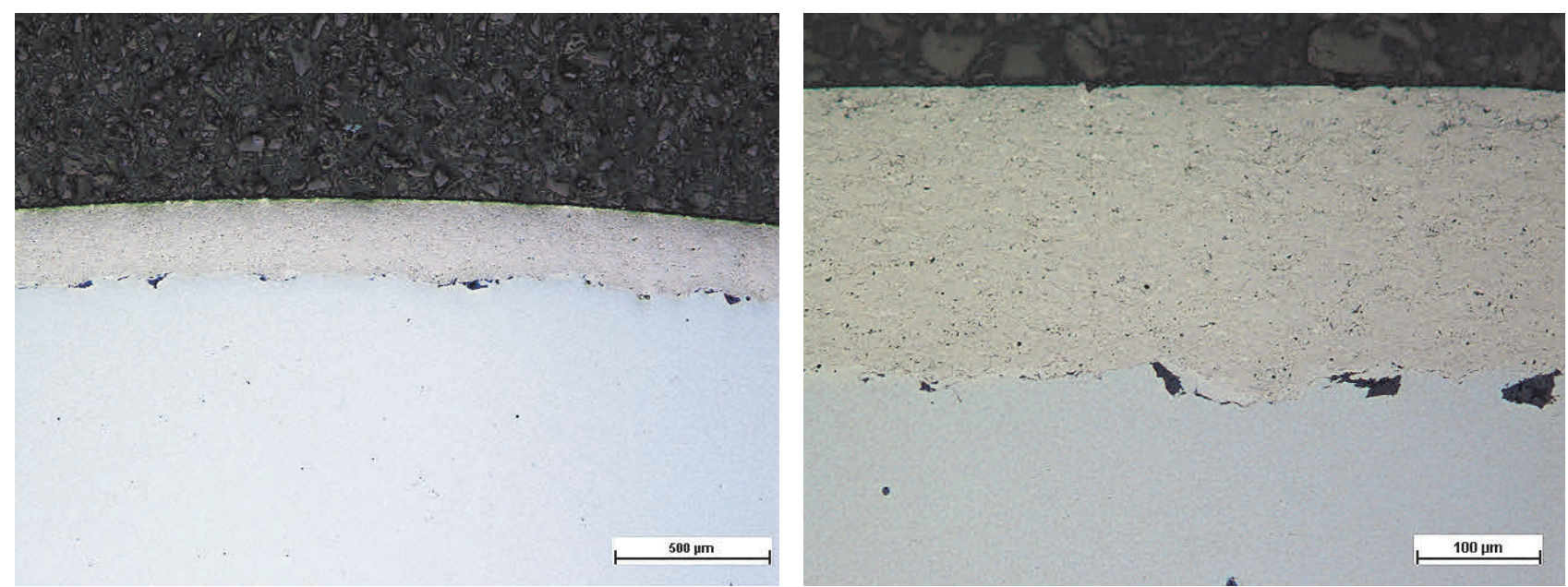

Figure 3 Optical micrograph of $\mathrm{Cr} 3 \mathrm{C} 2-\mathrm{NiCr}$ coating after exposition

The SEM analyses revealed the microstructural changes, caused by heat exposition. The precipitation of secondary carbides from supersaturated $\mathrm{NiCr}$ matrix can be observed. This phenomenon was previously described for samples, exposed in laboratory to the temperatures above $650{ }^{\circ} \mathrm{C}$ [2], but not for samples exposed under $400{ }^{\circ} \mathrm{C}$ [1]. The long-term heat treatment at $540{ }^{\circ} \mathrm{C}$ have also led to secondary carbide precipitation, which is supposed to restore the toughness of the matrix. Near the surface of the coating 
(Figure 4), the oxidation of carbide particles was recorded by SEM at several locations. It was not developed enough to disrupt integrity of the surface, but was significantly more developed that the same effect observed for similar coating (Figure 5), tested in the laboratory conditions [11] (steam; $609{ }^{\circ} \mathrm{C} ; 24 \mathrm{MPa} ; 116 \mathrm{~h}$ ). In both cases, the EDX analyses proved the presence of oxygen, carbide and chromium in the dark phase, while only chromium and carbon are presented in the middle of carbide particles.
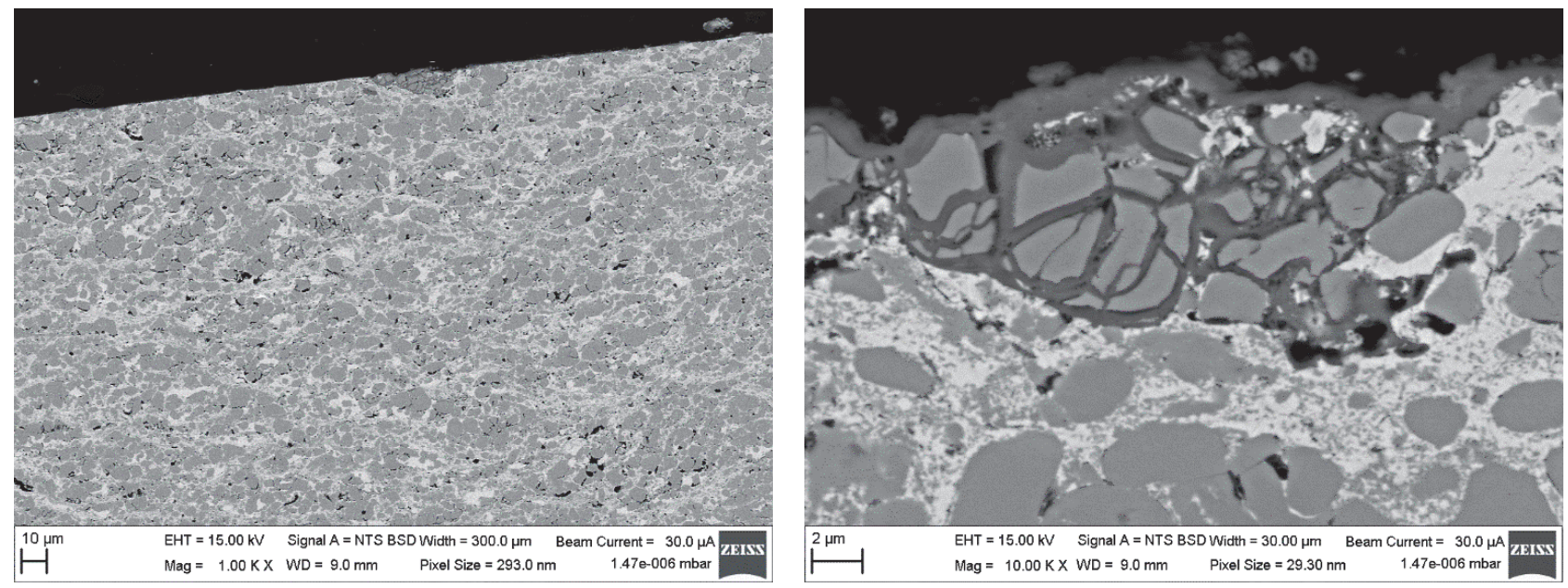

Figure 4 SEM micrograph of $\mathrm{Cr}_{3} \mathrm{C}_{2}-\mathrm{NiCr}$ coating after exposition in exposure channel ETU21
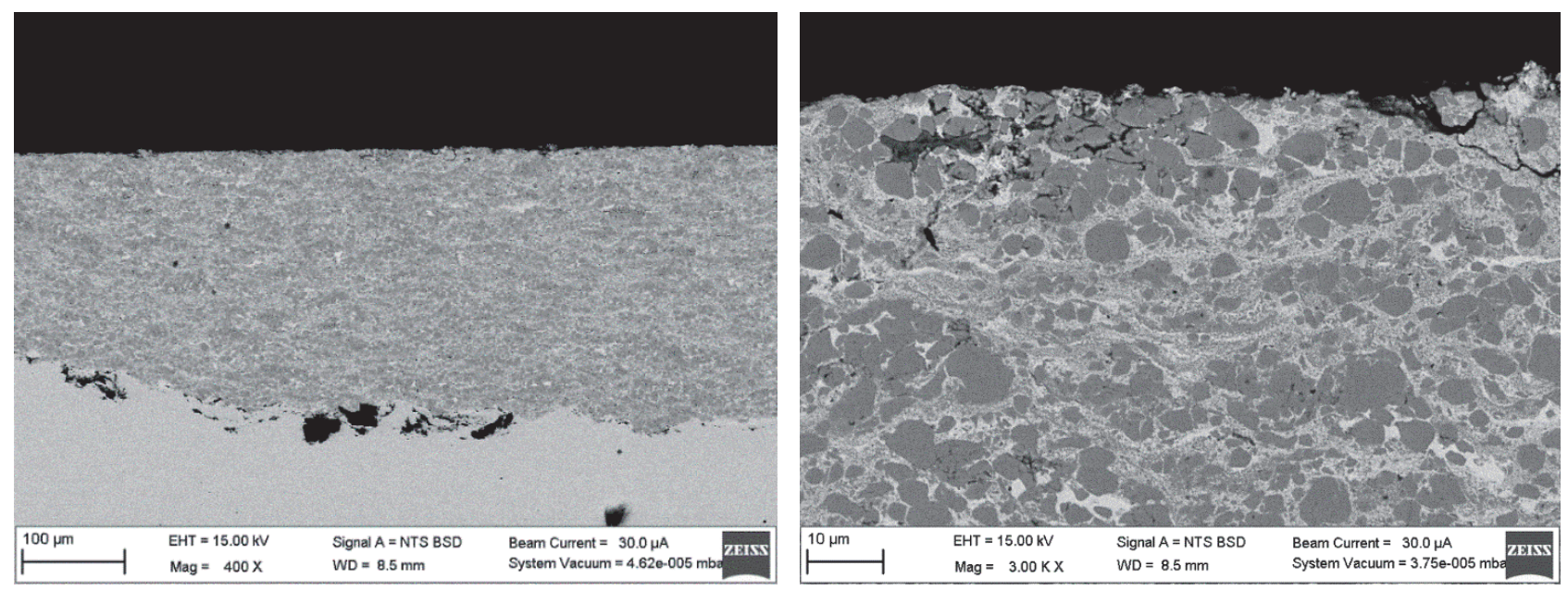

Figure 5 SEM micrograph of $\mathrm{Cr}_{3} \mathrm{C}_{2}-\mathrm{NiCr}$ coating after exposition in hot steam/high pressure autoclave VŠCHT

The XRD analyses confirm the SEM observation (Figure 6). The surface of the exposed coating is covered by $\mathrm{Cr}_{2} \mathrm{O}_{3}$ oxide, the expected $\mathrm{Cr}_{3} \mathrm{C}_{2}$ carbide and Ni-based matrix phase was detected. In the Figure 6, the comparison with the results obtained from our previous experiments is presented [11]. It can be seen, that the long-term exposition led to disappearance of non-stable lower carbides $\mathrm{Cr}_{7} \mathrm{C}_{3}$, that appeared after in the assprayed coating due to dissolution of carbides into matrix.

The microhradness measurement shows the evolution of related mechanical properties. While there are only small differences in microhardness of as-sprayed (920 \pm 46 HV0.3) coating and coatings after hot-air annealing (985 \pm 42 HV0.3) and steam annealing after short-term laboratory test $(1004 \pm 89$ HV0-3), the drop of microhardness was observed after 5,5 years of exposition at $450{ }^{\circ} \mathrm{C}(773 \pm 46)$. 


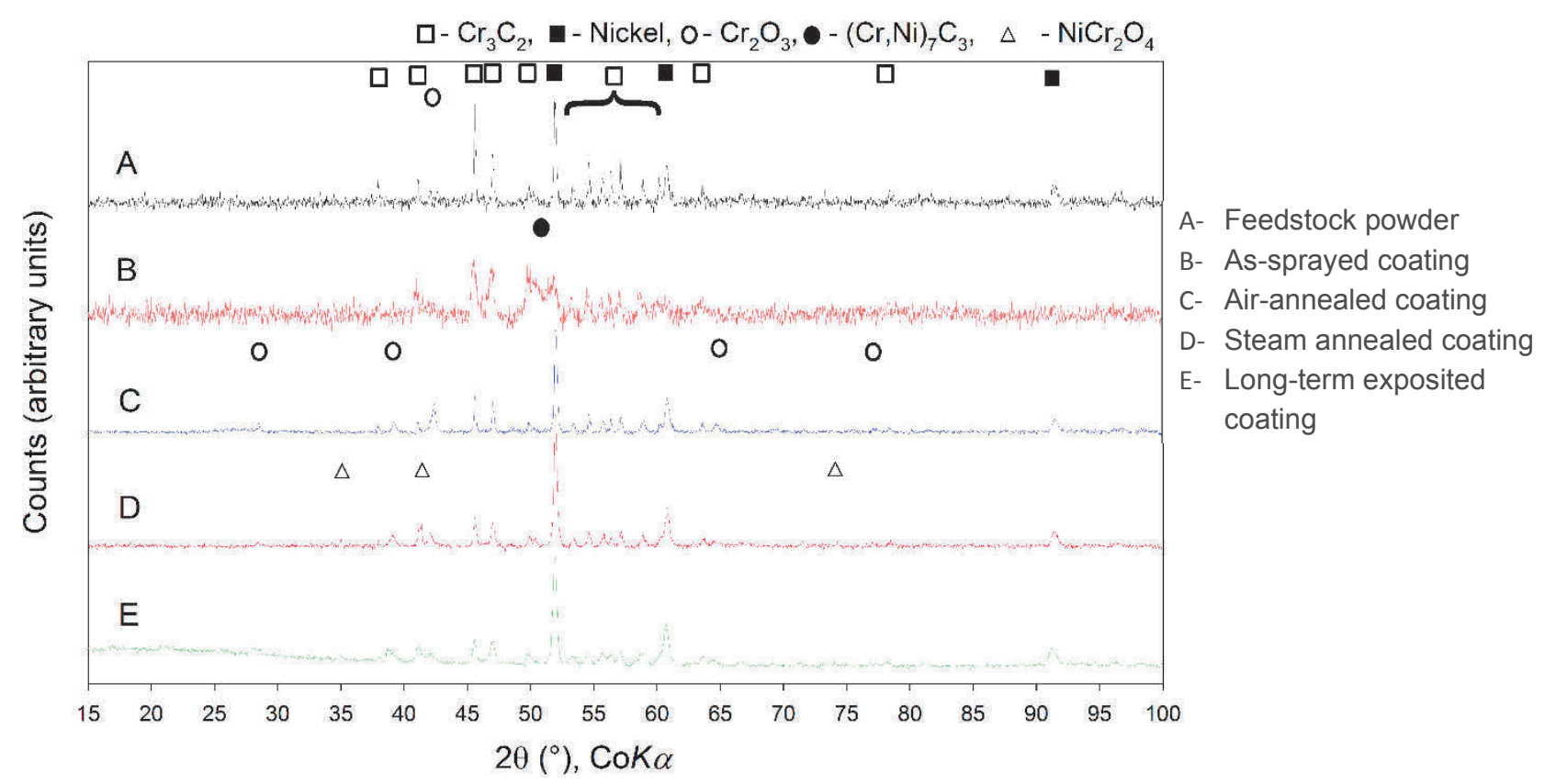

Figure 6 XRD phase analyses of $\mathrm{Cr}_{3} \mathrm{C}_{2}$ - $\mathrm{NiCr}$ powder and coatings in after exposition in different environments

\subsection{NiCrAl-Bentonite coatings}

The cross section of flame sprayed NiCrAl-Bentonite coating didn't show a major degradation, no cracks, delamination or spallation appears after 5.5 year of $540{ }^{\circ} \mathrm{C}$ exposition in ETU21 exposure channel (Figure 3b). The SEM and EDX analyses showed the changes in the composition of NiCrAl matrix (Figure 7). It can be seen, that the oxidational s well as phase transformation took place (Figure 8). On the surface of the exposed coating, only the Ni-based oxide was recorded by XRD analyses.
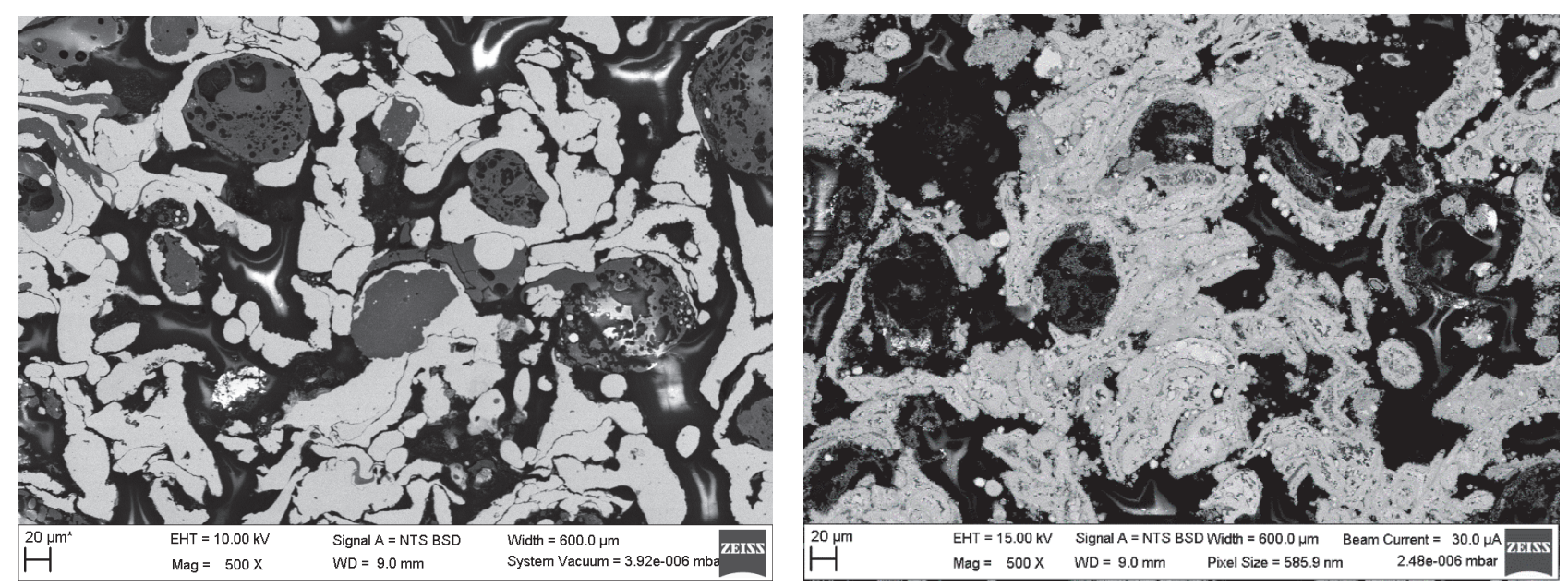

Figure 7 SEM micrograph of NiCrAl-Bentonite coating: a) as sprayed; b) after exposition in exposure channel ETU21

The mechanical properties of the exposed coating cannot be measured cross section of flame sprayed NiCrAlBentonite coating does not showed a major degradation, no cracks, delamination or spallation appears after 5,5 year of $540^{\circ} \mathrm{C}$ exposition in ETU21 exposure channel (Figure 3b). The SEM and EDX analyses showed the changes in the composition of NiCrAl matrix (Figure 7). It can be seen, that the oxidation as well as phase transformation took place (Figure 8). 

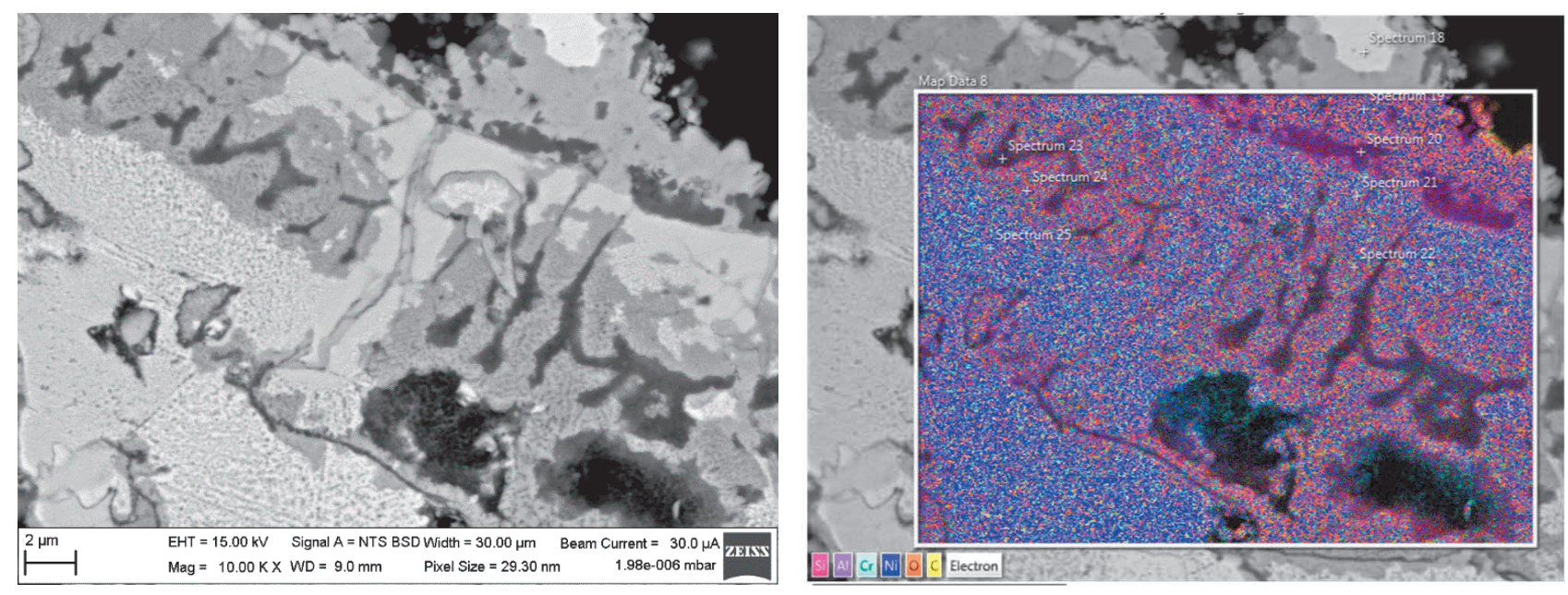

Figure 8 SEM micrograph of NiCrAl-Bentonite coating: a) as sprayed; b) after exposition in exposure channel ETU21

\section{CONCLUSION}

The results of 5.5 year long exposition in exposure channel ETU 21 confirmed the satisfactory lifetime of two types of thermally sprayed coatings in given environment. The detailed SEM and EDX analyses revealed oxidation of both coating materials, but not in a level leading to coatings destruction. Being applied on functionality parts, the combination of environment with mechanical loading can be expected. In this case, the negative effect of observed oxidation on the coating functionality cannot be excluded.

\section{ACKNOWLEDGEMENTS}

The paper has originated in the framework of the solution of the Technology Agency of the Czech Republic project number TE01020068. Authors thank Dr. Pavla Rudasová, Doosan Škoda Power s.r.o., for providing the exposition tests.

\section{REFERENCES}

[1] BOLELLI, G. BERGER, L.-M., BÖRNER, T., KOIVULUOTO, H., MATIKAINEN, V., LUSVARGHI, L., LYPHOUT, C., MARKOCSAN, N., NYLÉN, P., SASSATELLI, P., TRACHE.R., VUORISTO, P. Sliding and abrasive wear behaviour of HVOF- and HVAF-sprayed $\mathrm{Cr}_{3} \mathrm{C}_{2}$-NiCr hardmetal coatings, Wear, 2016. vol. 358-359, pp 32-50

[2] MATTHEWS, S., JAMES, B., HYLAND, M. High temperature erosion of $\mathrm{Cr}_{3} \mathrm{C}_{2}-\mathrm{NiCr}$ thermal spray coatings - The role of phase microstructure, Surf. Coatings Technol., 2009. vol. 203, no. 9, pp 1144-1153

[3] MATTHEWS, S., JAMES, B., HYLAND, M. High temperature erosion-oxidation of $\mathrm{Cr}_{3} \mathrm{C}_{2}-\mathrm{NiCr}$ thermal spray coatings under simulated turbine conditions, Corros. Sci., 2013. vol. 70, pp 203-211.

[4] JOHNSON, R.E. Mechanical characterisation of AISi-hBN, NiCrAl-Bentonite, and NiCrAl-Bentonite-hBN free standing abradable coatings. Surface and Coatings Technology. 2011. vol. 205, pp. 3268-3273

[5] MAOZAHONG, Y., BAIYUN, H., JIAWEN, H. Erosion wear behaviour and model for abradable seal coating. Wear. 2002. vol. 252, pp. 9-15

[6] MA, X., MATTHEWS, A. Evaluation of abradable seal coating mechanical propeties. Wear. 2009. vol. 267, pp. 1501-1510

[7] FIALA, P., HAJMRLE, K., SPORER, D., WILSON, S. Long therm air oxidation behaviour of selected abradable coatings at $650^{\circ} \mathrm{C} . \mathrm{In}$ GT 2010:ASME Turbo Expo 2010, 2010, Glasgow, Scotland, GB 
[8] HOUDKOVÁ, Š., MEDLíN, R. Analysis of damage of thermal spray coating $\mathrm{Cr}_{3} \mathrm{C}_{2}-25 \% \mathrm{NiCr}$, technical report no. NTC-VYZ-12-049, New Technology Research Centre, University of West Bohemia, Plzeň, Czech Republic, 2012 (in Czech).

[9] HOUDKOVÁ, Š. ČESÁNEK, Z., KAŠPAROVÁ, M., SCHUBERT, J. Spraying parameters study of HVOF Coatings, based on CrC, In METAL 2013: 22rd International Conference on Metallurgy and Materials. Ostrava: TANGER, 2013, pp. $x x-x x$.

[10] SVOBODOVÁ, M. ETU 21 EK analýza vzorků po 1. Době expozice na $450{ }^{\circ} \mathrm{C}$, technical report no. T615, UJP Praha, Czech Republic, 2014 (In Czech)

[11] HOUDKOVÁ, Š. ČESÁNEK, Z., SMAZALOVÁ, E., LUKÁČ, F. The High temperature Wear and Oxidation Behavior of CrC-Based HVOF Coatings, J Ther Spray Tech. 2018. vol. 27, pp, 179-195 